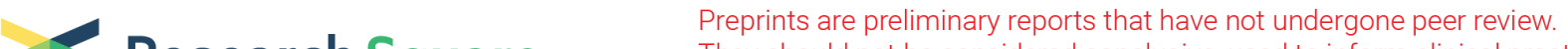 Research Square $\quad \begin{aligned} & \text { They should not be considered conclusive, used to inform clinical practice, } \\ & \text { or referenced by the media as validated information. }\end{aligned}$ \\ Reforming smallholder farms to mitigate agricultural pollution
}

\section{Yingliang Yu}

Jiangsu Academy of Agricultural Sciences

Yu Hu

Ministry of Agriculture and Rural Affairs

Baojing Gu ( $\sim$ bjgu@zju.edu.cn )

Zhejiang University https://orcid.org/0000-0003-3986-3519

\section{Stefan Reis}

Centre for Ecology and Hydrology Dorset: UK Centre for Ecology \&amp; Hydrology

Linzhang Yang

Jiangsu Academy of Agricultural Sciences

\section{Research Article}

Keywords: smallholder, agricultural pollution, farming model, yield, cost and benefit, fertilizer use

Posted Date: February 26th, 2021

DOI: https://doi.org/10.21203/rs.3.rs-267956/v1

License: (c) (i) This work is licensed under a Creative Commons Attribution 4.0 International License. Read Full License

Version of Record: A version of this preprint was published at Environmental Science and Pollution Research on October 1st, 2021. See the published version at https://doi.org/10.1007/s11356-021-166107. 


\title{
Reforming smallholder farms to mitigate agricultural pollution
}

Yingliang $\mathrm{Yu}^{1}, \mathrm{Yu} \mathrm{Hu}{ }^{2}$, Baojing $\mathrm{Gu}^{3, *}$, Stefan Reis ${ }^{4,5}$, Linzhang Yang ${ }^{1, * *}$

${ }^{1}$ Key Laboratory of Agricultural Environment of the Lower Reaches of the Yangtze River, Institute of Agricultural Resources and Environment, Jiangsu Academy of Agricultural Sciences, Nanjing 210014, PR China

${ }^{2}$ Research Center for Rural Economy, Ministry of Agriculture and Rural Affairs of China, Beijing 100810, PR China

${ }^{3}$ College of Environmental and Resource Sciences, Zhejiang University, Hangzhou 310058, PR China

${ }^{4}$ UK Centre for Ecology \& Hydrology, Bush Estate, Penicuik, Midlothian, EH26 0QB, UK

${ }^{5}$ University of Exeter Medical School, European Centre for Environment and Health, Knowledge Spa, Truro, TR1 3HD, UK

*Corresponding Author at College of Environmental and Resource Sciences, Zhejiang University, Hangzhou 310058, PR China

*** Corresponding Author at Key Laboratory of Agricultural Environment of the Lower Reaches of the Yangtze River, Institute of Agricultural Resources and Environment, Jiangsu Academy of Agricultural Sciences, 50 Zhongling Street, Nanjing 210014, PR China.

E-mail addresses: bjgu@zju.edu.cn (B. Gu), lzyang@issas.ac.cn (L. Yang)

\begin{abstract}
China's agriculture is dominated by smallholder farms, which have become major sources of negative environmental impacts including eutrophication, formation of haze, soil acidification, and greenhouse gas emissions. To mitigate these environmental impacts, new farming models including family farming, cooperation farming and industrial farming have emerged in recent years. However, whether these new farming practices would improve the economic and environmental performance as compared to the current smallholder farming has yet to be verified on ground level. In this paper, by using pilot farming cases within the watershed of Tai Lake, we found that alternative farming models produced $7 \%$ more crop yield, while using $8 \%$ less fertilizer, leading to an $28 \%$ decrease in pollutant emission per hectare. These alternative farming models have a $17 \%$ higher fertilizer use efficiency and 50\% higher profit per hectare. Compared to smallholder farming, these alternative farming practices invest $27 \%$ more resources into agricultural facilities, including advanced machinery, and have a younger, better educated labor force as a consequence of a larger farm size and more specialization. These input changes substantially increase fertilizer use efficiency and reduce agricultural pollution. Policy
\end{abstract}


arrangements to support and facilitate the uptake of these farming models will further promote the green development and sustainable intensification of agricultural production.

Key words: smallholder, agricultural pollution, farming model, yield, cost and benefit, fertilizer use

\section{Introduction}

Feeding the world's largest and increasingly wealthy population is a great challenge for China. To meet the population's food demand, one third of global chemical fertilizers is applied on China's cropland, while it only accounts to $9 \%$ of the global cropland area (FAO 2020). Unfortunately, more than half of these applied fertilizers is lost to the environment, leading to multiple negative impacts on the environment and on human health (Chen et al. 2014). Fertilizer and manure losses have become the dominant source of water pollution in China, contribute substantially to haze formation through ammonia $\left(\mathrm{NH}_{3}\right)$ emissions and global warming through nitrous oxide $\left(\mathrm{N}_{2} \mathrm{O}\right)$ emissions ( $\mathrm{Gu}$ et al. 2012,2013,2015). Furthermore, the overuse of fertilizers has also led to soil acidification and biodiversity loss through ammonium deposition (Guo et al. 2010; Yu et al. 2019). These environmental impacts have been estimated in costs ranging from 7 to $10 \%$ of China's agricultural gross domestic product (GDP) (Norse and Ju 2015). Solving agricultural pollution has become a grand challenge to safeguard sustainable development in China.

Land fragmentation is seen as a contributing factor to agricultural pollution with increasing economic prosperity (Jing et al. 2017; Ju et al. 2016). Chinese crop farming is dominated by smallholder farms with the average size of a land parcel typically utilized by a farm around 0.1 hectare (ha), and only $2 \%$ of rural households manage a farm area of more than 2 ha (Wu et al. 2018). Smallholder farming reduces opportunities and the viability of adopting advanced agricultural technologies due to high opportunity cost $(\mathrm{Hu}$ et al. 2019), despite the availability of technologies which are proven to be effective tools to increase nitrogen use efficiency (NUE) without compromising crop yield (Lassaletta et al. 2014). NUE is normally used to indicate the efficiency of fertilizer use, which is estimated as harvested crops divided by total nitrogen input (Zhang et al. 2015). Due to the low NUE, much higher fertilizer application rate is found in smallholder farms to maintain a high yield, compared to fertilizer rate in large-scale farms (Ju et al. 2016). Consequently, a large amount of nutrient loss leads to economic inefficiency and substantial environmental pollution and greenhouse gas (GHG) emission from these smallholder farms.

A reform of the currently predominant smallholder farm types is potentially one of the most promising measures to stimulate both economic growth and rural development (Reardon and Timmer 2014). In the context of expanding farm size, China introduces new operational farming models to mitigate agricultural non-point source pollution, 
including family farming, cooperation farming and industrial farming. These new farming models typically vary in their practices including agricultural inputs, management approaches, farmers' education and knowledge, etc. Previous studies regarding these new farming models mainly focused on their socioeconomic aspects, such as changes of the land tenure system and farmers' income (Du and Liu 2017; Wang 2015), but rarely considered environmental performance. Furthermore, there is an ongoing debate on whether modern agricultural models reduce yield and pollution or increases them (Ren et al. 2019; Wu et al. 2018). As these new farming models have only recently been introduced, they are only found in some of the more developed regions in China, however with a rapidly increasing trend. The overall performance of these new farming models and how their operation may affect agricultural pollution has so far not been evaluated in detail.

Attributes of both farmers and croplands potentially affect farming strategies, including the amount and type of nutrient and economic inputs and machinery use. In this paper, we analyze the performance of alternative farming models with regard to crop yields, nutrient inputs and losses, costs and profits in comparison to smallholder farming, based on survey and monitoring data from a paddy site within the watershed of Tai Lake. In addition, we discuss and review the driving forces characterizing these alternative farming models, such as technology use, educational level, age of farmers, etc. As smallholder farming still plays an important role globally, this study will provide novel insights into the different environmental and economic performance indicators of different farming models, and thus contribute to the green development of agriculture and provide solutions to global Sustainable Development Goals (SDGs).

\section{Methods}

Study site. In order to investigate the effects of alternative farming models on agricultural pollution, the whole Wuzhong District (an administration unit like a county) was chosen as a representative study site due to its vulnerable environment and well-developed economy. It belongs to the Tai Lake watershed in the Yangtze Delta Region, an area where serious eutrophication events frequently occur. Thus, Wuzhong is one of the earliest pilot regions for a widespread reform of farming models. The climate, soil and economic parameters of farms within Wuzhong are similar, making it a suitable region for a case study on the reform of smallholder farming. It has subtropical climate with an annual mean temperature of $16.6{ }^{\circ} \mathrm{C}$ and precipitation around $1,000 \mathrm{~mm}$, with rain mainly occurring during April to August. Paddy fields are the main land use type for rice production with a history of thousands of years, and the cultivated paddy area was around 1,900 ha in 2018. Cropland soil is gleyed paddy soil evolved from lacustrine deposits.

Nutrient loss from crop production has substantial impact on the water quality of Tai Lake. Agrotechnicians assembled by government provide scientific guidance to the farmers who operate larger farms. Meanwhile, rapid economic development drives young 
people to seek work in urban areas instead of farming. To ensure the cultivation of croplands, the local government in the Wuzhong District promotes cropland transfer. The fragmented croplands are collected from smallholder farmers and made available for lease by alternative farming models. The number of smallholder farms declined from 2,047 in 2013 to 193 in 2018, with an increase in the number of alternative farming models.

Farming models. Smallholder farming was originally initiated as part of the scheme of Household Contract Responsibility System (HCRS) in 1978 in China. The HCRS allocates croplands to all rural residents evenly in each village, today on average 0.5 ha cropland per rural household, considering both the quantity and quality of their lands. Smallholder farms are normally managed by older family members (average age 63 years) with a main purpose of food self-sufficiency (Table 1). Farmers would not likely operate their farms with increased intensity if they had access to better machinery and knowledge (due to a generally low educational level) given the low-income they extract from their small pieces of land, leading to mis-use of fertilizers and low fertilizer use efficiency.

Alternative farming models normally have a larger land area (i.e., 7-60 ha) through renting lands from smallholder farmers and a younger workforce (on average 40-45 years old). There farming practices still vary substantially, but large-size land holders are all prioritizing economic benefit from marketing their farm produce. Family farming is still conducted by family members with additional labor rental during busy seasons. Due to a lack of capital investment, knowledge and access to machinery, family farming is still primarily labor intensive, not supported by knowledge-based modern management methods. The household income element of larger farms from agriculture is comparatively higher than that of smallholder farms owing to the larger farm size, and family farmers also have a higher degree of willingness to try new technologies and better management approaches on their farms.

Cooperation farming normally incorporates several family farming units with larger land area, a higher degree of machinery uses through sharing among members and involvement of agrotechnicians. This higher rate of machinery and knowledge inputs could potentially increase both crop yields and fertilizer use efficiency. Due to the shared use of machinery and agrotechnicians, their input cost per unit land is lower, resulting in a higher profit-cost ratio. The main purpose of cooperation farming is profit, thus, best management practices such as 4R stewardship (right fertilizer type, right amount, right place, and right time) are implemented to maximize yield while minimizing fertilizer input.

In addition to the application of best management practices from cooperation farming, industrial farming emphasizes in addition brand effect and crop quality as important aspects. Industrial farms employ professional managers to solely focus on marketing and sales. Thus, higher crop prices are typically achieved by industrial farms, and relatively 
lower expected yield and fertilizer use compared to that of cooperation farms as a function of the ambition to maximize the profit. Financial support of industrial farming is of high importance to enable high intensity of machinery use and knowledge-based management, which are more commonly used compared to other farming models.

Data sources. Attributes of farmers, cropland and agricultural input of each farming model were obtained from Wuzhong agricultural bureau (Table 1). Besides smallholder farming, family, cooperation and industrial farming are alternative farming operation models which emerged as a result of cropland transfer. The average area of farm size increased by over 500 times after cropland transfer. A household survey was conducted in November 2018 among 63 farms (including 14 smallholder, 25 family, 14 cooperation and 10 industrial farms), which occupied $79 \%$ of the whole paddy area in the Wuzhong District. Detailed data of yield, straw harvested, agricultural input (fertilizer, pesticide and field management input such as irrigation and machinery), and profit were collected. Furthermore, paddy plants (aboveground biomass) were sampled, and the nitrogen and phosphorus content of these grains and straw were measured directly.

Nitrogen use efficiency (NUE). The nutrient accumulated in aboveground biomass is treated as the effective part of the nutrient due to fertilizer use. To reflect the fertilizer use efficiency, the NUE in each farm were calculated as follow (Zhang et al. 2015):

$$
N U E_{i j}=A N_{i j} \times\left(F N_{i j}+B N F+D E P\right)^{-1}
$$

where, $N U E_{i j}$ is the nitrogen use efficiency; $A N_{i j}$ is amount of nitrogen in aboveground plant tissues ; $F N_{i j}$ is the amount of nitrogen fertilizer input; $B N F$ is biological nitrogen fixation (Gu et al. 2015); DEP is nitrogen deposition (Yu et al. 2019); $i$ represents four farming models and $j$ represent the number of the farms in each model. No manure is applied in the study area.

Fertilizer loss. The optimal nitrogen input should be close to the amount in aboveground plant tissues ( $\mathrm{Ju}$ and $\mathrm{Gu} 2014$ ), and the difference between plant material harvested and fertilizer input was considered as surplus that would be lost via leaching, runoff, volatilization etc., causing agricultural pollution (Zhang et al. 2019). Here, the fertilizer losses $\left(L C o f_{i j}\right)$ from farms were estimated as follow:

$$
\begin{aligned}
& N L \operatorname{Cof}_{i j}=\left(F N_{i j}-A N_{i j}\right) \times C o n N \\
& P L C o f_{i j}=\left(F P_{i j}-A P_{i j}\right) \times \operatorname{Con} P \\
& \operatorname{LCof}_{i j}=N L \operatorname{Cof}_{i j}+P L C o f_{i j}
\end{aligned}
$$

where, $N L C o f_{i j}\left(P L C o f_{i j}\right)$ is the amount of nitrogen (phosphorus) lost from 1 ha paddy field; $A N_{i j}\left(A P_{i j}\right)$ is the amount of nitrogen (phosphorus) in aboveground plant tissues ; $F N_{i j}\left(F P_{i j}\right)$ is the amount of nitrogen (phosphorus) fertilizer input; ConN is assumed as $50 \%$ and $\operatorname{ConP}$ is assumed as $20 \%$ to estimate their environmental pollutions ( $\mathrm{Ju}$ et al. 2009; Liu et al. 2016). The difference between ConN and ConP typically arises because 
more phosphorus is potentially accumulated in the soil compared to nitrogen if surplus occurred, and a large part of the nitrogen surplus is converted to $\mathrm{N}_{2}$ which does not have environmental or climate effects. Meanwhile, accumulated nitrogen or phosphorus can also be reused in following seasons.

Annual fertilizer loss in the whole study region was calculated based on the area used by different farming models and the coefficient of fertilizer loss.

$$
\begin{aligned}
& N L_{k}=\sum_{i} \sum_{j} H_{i j k} \times N L C o f_{i j} \\
& P L_{k}=\sum_{i} \sum_{j} H_{i j k} \times P L C o f_{i j}
\end{aligned}
$$

where, $N L_{k}(P L k)$ is the total amount of nitrogen (phosphorus) loss in study region; $H_{i j k}$ is area of farm $j$ with $i$ farming model; $k$ represents the years from 2013-2018.

Cost and profit analysis. The economic cost in this study includes non-fixed and fixed inputs. The costs for fertilizer and pesticide application are both classed as non-fixed inputs, and expenses for field management including machine use, ploughing and harvest, etc. are fixed inputs. Profit mainly refers to income from selling rice.

Labor productivity. Total labor input (including temporary employee and managing input) in the rice growing season in each farm was recorded. Because paddy cultivation only occurs over 6 months in the study region, every 6 months labor input was calculated as one farmer's annual labor input. Labor productivity was estimated from the total profit divided by total labor input.

Model analysis. The differences in farm size, attributes of farmers, agricultural management such as machinery use (Table 2) were compiled to estimate how the agricultural input and pollution emission would response under different farming models. Models are built as below:

$$
\begin{aligned}
& A_{t}=\alpha_{0}+\alpha_{1} \text { CroplandsAttributes }_{t}+\sum_{k} \alpha_{k} \text { Controls }_{k t}+\varepsilon_{t} \\
& \text { EI }_{t}=\beta_{0}+\beta_{1} \text { CroplandsAttributes }_{t}+\sum_{k} \beta_{k} \text { Controls }_{k t}+\varepsilon_{t}
\end{aligned}
$$

where subscript $t$ denotes each production unit. $A I_{t}$ represents agricultural input for unit $t$, including fixed (such as machinery) and non-fixed (fertilizers) input. $E I_{t}$ represents environment impact for unit $t$, including NUE and pollution emission.

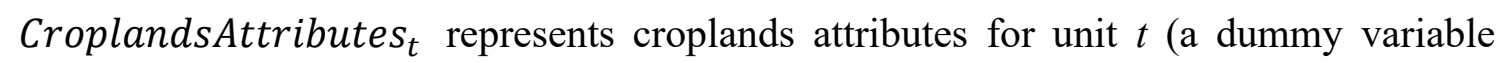
which represents the farming models). Meanwhile, Controls $s_{k t}$ are various control variables affecting NUE or pollution emission, including farm size, age or educational level of farmers, and frequency of machinery use, etc. $\alpha$ and $\beta$ are estimated coefficients; and $\varepsilon_{t}$ is the residual error. Both ordinary least square and two-stage least square methods are used to estimate the effects of these impact factors on the performance of different farms and their robustness. The residual error follows a normal distribution 
which helps to constrain the estimates of coefficients and reduces the effects from omitted variables.

\section{Results}

Yield and fertilizer use. As the alternative farming models are more focused on economic viability due to primarily producing crops for sale, they pay more attention to maximizing profits through higher rice yields, while lowering cost by reducing fertilizer use per ha with an overall larger farm size. Their yields are 2-13\% higher, while using 3$13 \%$ less fertilizer compared to smallholder farms; however, the difference is not statistically significant due to the large variations in farming practices (Fig. 1). Smallholder farmers still hold the opinion that higher fertilizer input equals higher yield, but do not have any actual data that would allow them to notice that their yield is lower than the maximum potential yield due to overuse of fertilizers.

Family farmers are typically open and keen to try new fertilizers, and a large variety of fertilizers are thus used on these farms. However, there are still knowledge gaps regarding best management practices. Compared to smallholder farms, family farming only increases paddy yield by $6 \%$, with $3 \%$ less fertilizer use.

Under the guidance of agrotechnicians, cooperation farming performs the best regarding highest yield and lowest fertilizer use. However, industrial farming, which is also guided by agrotechnicians, does not achieve the highest yields, as it could be expected. One key reason may lie in the fact that managers focus on raising the rice price rather than increasing yield, in the context of a very large farm size (Table 1). For industrial farming, although its yield increase is only $2 \%$ compared to that of smallholder farming, a reduction in fertilizer use by $10 \%$ increases profit margins.

Due to the increase in yield and decrease in fertilizer use, alternative farming models have a 5-29\% higher NUE (Fig. 1d), resulting in 9-38\% less fertilizer loss (Fig. 1c). The high NUE in industrial farming was inconsistent with the low yield due to low application of pesticides. Industrial farms prefer 'low pesticide input' as a selling point to achieve a higher sales price for rice produced.

Cost and profit. Smallholder farming has a relatively higher non-fixed input ratio $(\sim 60 \%$ of total input), while their fixed input ratio is lower compared to that of alternative farming models (Fig. 2a). This suggests that smallholder farmers prefer to use more fertilizers and pesticides to increase yields on their small land area where it is not economically efficient to invest in machinery or training. The non-fixed input is $22-48 \%$ lower in the alternative farming models, except for the case of family farming, which has a $6 \%$ higher total cost than smallholder farming. Fixed input ratios in cooperation and industrial farming decrease with the increase of farm size due to scale effects, i.e. the fixed input per ha cropland decreases with farm size, because these farms can share fixed input factors such as machinery. 
Compared to smallholder farming, the rice price is $11-36 \%$ higher in alternative farming models, which leads to a significant increase in total profits, combined with an increase in crop yield (Fig. 2b). The profit-cost-ratio (profit/cost) in industrial farming is twice that of smallholder farming (Fig. 2c). A higher profit-cost-ratio motivates more younger people consider careers in agricultural production in these alternative farming models. In contrast, the low profit-cost-ratio in smallholder farming encourages young people to leave rural areas in favor of moving to cities, leaving only elderly people to work on small paddy fields. The profit-cost-ratio in family farming is the lowest among alternative farming models due to its relative low profit generation, at high cost (Fig. 2). As a result, more than $80 \%$ of family farm holders have given up rice planting within 3 years because of this low profit-cost-ratio. Accordingly, the labor productivities are 114206 times higher for the alternative farming models compared to smallholder farming

(Fig. 2d). Farmers can generate more profit after consolidating the fragmented croplands to operate alternative farming especially industrial farming, utilizing less labor input due to a higher degree of mechanization and knowledge inputs, which in turn promote higher NUE and reduce fertilizer losses and thus environmental pollution.

Regional agricultural pollution. The number of smallholder farms in the study region used to be over 30,000 before 2006, but has been continued to decline with economic development and urbanization during the past decade. In 2013, there were still over 2,000 smallholder farms, accounting for $6 \%$ of the total area of rice planting. By 2018 the number of smallholder farms had been further reduced to less than 200 with their share of farm area now at $<1 \%$ (Fig. 3a). The continuous reduction of area share was also found for family farms after 2016 given its low profit-cost-ratio compared to the other alternative farming models (Fig. 2). Family farms accounted for over half of the paddy area during the period 2014-2016 when the reform had just started, and family farms were easier to build given its smaller farm size compared to cooperation and industrial farming. But it decreased quickly to $19 \%$ by 2018 because of low profit. A similar trend was also found for cooperation farms, which accounted for 33\% of total paddy area in 2015, but then sharply declined to $16 \%$ by 2018 . The land area managed by both family and cooperation farms reduced by one third by 2018 , compared to the average land area managed in 2013. All these changes are mainly due to the increase of industrial farms that have a much higher profit and income per labor (Fig. 2), accounting for more than half of paddy area since 2017 . These changes suggest that crop production had generally moved towards more market-oriented production models, given that industrial farming offers the highest profit-cost-ratio and labor productivity levels.

With the changes in planting area for different farming models, the total fertilizer loss from paddy fields varied substantially in the period between 2013 and 2018 (Fig. 3b). In the period between 2013 and 2016, fertilizer losses changed only slightly given family farming dominating the total area of paddy field, which has a similar fertilizer loss pattern 
with smallholder farms (Fig. 1c). However, fertilizer loss substantially reduced after 2016, when industrial farming begun to dominate the total area of paddy fields, especially in the case of $\mathrm{N}$ fertilizer losses. The decrease in $\mathrm{N}$ fertilizer losses has been estimated at $12-16 \%$ after 2017 as a result of the increased area share of industrial farms which can lead to reductions of up to $38 \%$ of fertilizer loss (Fig. 1c). Yet, agricultural pollution in the study region still has potential for further reduction, if the area share of cooperation and industrial farming would be increased in the future (Fig. 3a).

\section{Discussion}

Agricultural input mix. Fertilizer constitutes a non-fixed input in our analysis, and is the primary source of agricultural pollution (Chen et al. 2014). Fixed inputs may potentially promote nutrient uptake by plants, thus reduce fertilizer loss, for instance, layered fertilization via machinery and irrigation can increase crop yields and thus a higher nutrient uptake (Ke et al. 2018). Most smallholder farmers do not have sufficient data or knowledge about the amount of nutrients required by their fields, leading to overuse and mis-use of fertilizers which not only reduces crop yield, but also increases pollution (Ju et al. 2009; Zhang et al. 2016). Previous studies suggested that reforming smallholder farming through increasing farm size could reduce fertilizer use and loss, but can also reduce crop yield, even though only to a small extent (Adamopoulos and Restuccia 2014; Wu et al. 2018). In this paper, we found that crop yield is not reduced, but actually increased in alternative farming models (Fig. 1). This may be due to the fact that the overuse of fertilizers has gone beyond the turning point of the fertilizer-yield response curve in smallholder farms. Machinery and knowledge-based management in alternative farming models thus could help to reduce the randomness of fertilizer application and at the same time increase crop yield (Jing et al. 2017).

The use of fertilizer application machinery in the study region resulted in a $10 \%$ improvement of NUE and a 35\% reduction in pollutant emissions without any yield decline. Farmers utilizing alternative farming models typically emphasize the reduction of non-fixed inputs because the large farm size results in large total non-fixed input costs if they cannot reduce the non-fixed input per ha. For each 1\% NUE improvement, these farms could save around 150 US dollar (USD) of fertilizer input for a farm with a size of 10 ha. Therefore, there is a strong economic incentive to minimize non-fixed inputs per ha, while increasing the investment in fixed inputs that can have a scale effect, i.e., a larger farm size with lower fixed cost per ha. Nevertheless, the same strategy is not viable for smallholder farmers given their small farm size which makes it not cost-effective to invest in machinery. Long-term habits of manual farm management are barriers to the willingness to adopt new methods or technologies (Hu et al. 2019), which require more fixed inputs such as training for the knowledge and machinery.

However, these fixed inputs are mainly labor-intensive activities in family farms, in contrast to the higher utilization of machinery in cooperation and industrial farms. 
359 Fertilizer is still applied by hand broadcasting in family farming, and the expensive labor

360 costs in the study region thus increase the cost of field management (Zhong 2016).

361 Broadcasting of fertilizer increases the risk of losses and low NUE, which forces farmers

362 to apply more fertilizer than needed to meet the demands for crop growth(Ju et al. 2009).

363 Compared to family farms, the larger farm sizes of cooperation and industrial farms make

364 it easier to invest into agricultural machinery. The high fixed input ratio in cooperation

365 and industrial farming contributes to not only a reduction in total fertilizer use, but also

366 supports an intensive management regime which can improve the NUE. The fixed input

367 such as machinery and knowledge-based management in cooperation farms help to

368 maximize crop yields, while minimizing fertilizer loss by increasing NUE. Due

369 cooperation farms selling rice at market prices, the way to maximize profit-cost-ratio is

370 to increase yield while reducing fertilizer use. As a consequence, we found highest yield

371 and lowest fertilizer use in cooperation farms (Fig. 1). The yield increase per $\mathrm{N}$ fertilizer

372 use is highest in cooperation farms $\left(53 \mathrm{~kg} \mathrm{~kg}^{-1}\right)$, compared to 49 and $42 \mathrm{~kg} \mathrm{~kg}^{-1}$ in family

373 and industrial farms, respectively. However, the low protein content in the rice from

374 cooperation farms reduces its NUE, compared to that of industrial farms, which place

375 more emphasis on the quality of rice with a higher protein content in order to achieve a

376 higher unit price.

Farmer and farm size. The individual attributes of farmers, as decision-makers for their farming operation, play a vital role for their producing strategy. There is a tendency towards increasing risk aversion and decreasing interest in trying new approaches with farmers' aging (Hu et al. 2019). Here, we indeed find that the NUE decreases and fertilizer loss increases with farmers' age. As a consequence, labor productivity declines with the farmers' age. Farmers at middle ages perform better with less fertilizer and pesticide use, higher NUE and less pollution emission (Table 2, Fig. 4). Middle-age farmers have overall better farming knowledge and experience than younger farmers and are more open to trying new technologies than older farmers. Meanwhile, based on the information provided by local agricultural technicians, farmers at middle ages are more open to adopt advice for fertilizer application reduction methods, compared to other ages. Farmers between 40-50 years of age showed great enthusiasm to contribute to our survey and were keen to obtain follow-up feedback and further guidance from evaluation of the survey results. Compared to smallholder farmers, farmers in alternative farming models are on average more than 10 years younger, and most of these farmers are between 40-50 years of age (Table 1). Consequently, these new farmers achieve much higher labor productivity, which in turn leads to a better performance on paddy production, not only regarding yield, but also in terms of environmental pollution control.

Beyond age, educational level has emerged as another important factor. With socioeconomic development, the overall educational level is increasing in China, which 
implies that younger adults may on average have obtained a higher educational level than their elders. Farmers with higher educational levels are more likely to adopt advanced agricultural technologies (Waller et al. 1998). Our results confirm this and support the hypothesis that NUE increases while fertilizer loss decreases with educational level (Fig. 4). This results in increasing labor productivity from paddy production with educational level. Compared to smallholder farmers, farmers in alternative farming models have a higher educational level, and industrial farming shows the highest educational level of their laborers. Nevertheless, communication with local agricultural technicians may moderate the differences in agricultural performance due to farmers' educational level (Table 2). Investing in agricultural technician advice has been proven to be an effective approach to mitigate agricultural pollution (Fan et al. 2019).

Mismanagement is another major reason for the low NUE and high fertilizer loss in smallholder farms. Our study region is one of the well-developed regions in China. Income from rice production is a negligible element in supporting the livelihood of smallholder farmers. Most of smallholder farmers maintain rice production just because they have traditionally planted for their whole life and are used to eating their own rice. Without the purpose of making a profit, smallholder farmers do not pay much attention to improving paddy management (Table 2 ). Their production primarily satisfies their own food demands, and any surplus is sold at a low price on local market. In addition, the small farm size reduces their sensitivity to the total cost of paddy production. This finding is consistent with previous studies, where smallholder farmers were less sensitive to fertilizer price changes due to the low proportion of income derived from agricultural production (Ju et al. 2016). In contrast, the income from non-agricultural work enables smallholder farmers to spend more on fertilizer or pesticide purchases, but is not sufficient to allow for investments in expensive fixed inputs such as machinery (Ebenstein 2012).

Several studies attributed the change of agricultural inputs (Hu et al. 2019; Wu et al. 2018) and environmental impacts to farm size (Ren et al. 2019; Wang et al. 2017). In this paper, we indeed find that farm size is a crucial factor affecting agricultural fixed input ratio, farmers' age and educational level (Fig. 5). With the increase of farm size, fixed inputs will have a lower relative cost per ha and higher profit per unit of labor, benefiting the performance of agricultural production, both regarding yield and crop price, as well as for pollution mitigation (Table 2). This study demonstrates that NUE increases with farm size. The influence of NUE on profit realization is greater for larger cropland areas. Farmers who manage large-scale farms spend more time and efforts on NUE improvement to achieve higher cost-profit ratios. The income from paddy production in smallholder farms only contributes a small portion of the total family incomes, while the profits realized from cooperation and industrial farms typically provide a large share or even the entire income for full-time farmers. 
439 Socioeconomic barriers. To enable the transition to new farming models, we need to

440 recognize and address socioeconomic barriers related to family structure and population

441 displacement because of the reduced labor requirements under the new farming model.

442 In fact, labor shortage in rural areas affecting smallholder farms is already happening

443 due to an aging society in China. Many croplands in sloped areas have been abandoned.

444 We also found the average age of smallholder farmers from our study region is close to

44565 , which is the average retirement age in China, and younger people generally work in

446 urban areas where they can realize a much higher income. Before the reforms took hold,

447 average net income per ha was around 1,700-2,500 USD per year, and each rural

448 household owns 1/15-2/15 ha of cropland. In contrast, after the reforms, government

449 one-off payments of 22,000 USD ha-1 to buy out the operating right of smallholders'

450 farms, enabled the consolidation into large-scale farms for the new farming models. In

451 addition, government transfer payments of about 13,000 USD ha ${ }^{-1}$ were made as social

452 and medical insurance for smallholder farmers who gave up their croplands. This

453 resulted in a 5-fold increase in smallholder farmers' agricultural income. That is the

454 reason why nearly all smallholder farmers in our study region gave up their lands within

4553 years. Elderly farmers retired after giving up lands and remained in their villages.

456 Younger farmers either opted to be incorporated in the new large-scale farms in villages

457 or migrated to cities to take up non-agricultural jobs, where they can generate higher

458 incomes in addition to social and medical insurance payed by governments. These

459 findings suggest that the farming reform requires strong finical support from

460 government to be effective. New farming models can increase the productivity and this

461 increased productivity in turns generates part of the reform costs. Financial transfers

462 from urban areas contribute as well to agricultural subsidies because the farms provide

463 food for the whole society - urban and rural.

Implications. Reforming smallholder farming has resulted in changes in agricultural performance. This paper illustrates the advantages of alternative farming models, such as reducing agricultural inputs and environmental pollution, while realizing higher agricultural profit ratios. However, the best pathways to further promote the green development of agriculture still presents a challenge, which requires multiple stakeholders to work together.

Firstly, promoting and providing a stable operating space for the alternative farming models, especially cooperation and industrial farming, is essential. Currently, the alternative farming models are all relying on the cropland transfer from smallholder farms. In the study region, cropland rental contracts are signed every year due to the rapid change of land use with economic development. We have found this the short operating time scales based on short-term leases of cropland increases the risk for alternative farming models to invest in fixed inputs. They are not willing to invest in machinery or field consolidation, which would require long-term security of farming operations to be viable 
(depreciation of equipment over time, bank loans etc.). Instead, they increase non-fixed inputs for profit maximization, before the land lease ends. Previous studies also found that farmers have a tendency towards increasing non-fixed input (in particular fertilizer and pesticide use) in the context of short-term land leases (Fan et al. 2019), and it may even result in predatory use of land (Ye 2015). Sustainable development pathways for agriculture will require long-term management strategies. For example, long-term landleases and guaranteed cropland operation rights will encourage farmers within alternative farming models to increase their fixed inputs (Yan et al. 2019). Besides, more focus on long-term maintenance and improvement of soil quality and fertility will be fostered when farmers have the security to produce crops on the same field for a longer time period. The long-term cropland operation rights will also incentivize farmers to play a vital part in agricultural pollution control, as it affects their own production and living environment.

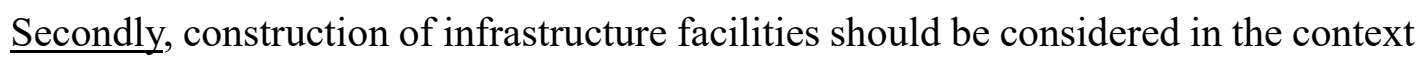
of cropland transfer. Poor road conditions and other infrastructure are major problems contributing to cropland fragmentation, which inhibit the use of agricultural machinery. In the study region, smallholder farms and some family farms face such problems, which hinder their adoption of advanced agricultural technologies. Nevertheless, croplands accessible by well-maintained roads normally have higher rental price, increasing production costs. Recently, local government actors prioritize road construction and provide subsidies to industrial farmers if they invest in improving road conditions around their farms. Chinese central government also issued a policy of giving 'Priority to Development of Agriculture, Rural Areas and Farmers' in January 2019 to accelerate the construction of high-standard croplands. Investment in the infrastructure construction around croplands is a vital foundation for reforming smallholder farms to develop modern green agriculture with a higher yield, lower pollution and higher income.

Last but not the least, more education and training are needed for farmers. Farmers should be trained in best management practices, for example, the recommended amount of nutrient application based on soil fertility and paddy type specific for their farms. Agricultural support services for emergencies, such as flooding, diseases and insect plagues should also be offered to increase resilience to agricultural risks, especially for alternative framing models, which are highly depended on the income from crop production. These services will help these alternative farming models to survive and maintain the food security for the whole country. Moreover, technical training should also be provided to improve farmers' ability to use modern agricultural machinery. Furthermore, government should increase information provision on available agricultural subsidies to farmers. Although Chinese government has withdrawn most of fertilizer subsidies since 2008, some subsidies for special fertilizer types are still available. In the study region, cropland soils are P-rich. Hence, the local agricultural policy department promotes special fertilizers with low $\mathrm{P}$ content, and farmers can purchase them at a $30 \%$ reduced price. However, many local farmers were not aware of the existence of these 
economic incentives, not only because of a general lack of knowledge on best management practices, but due to information asymmetry compared to policy makers and agroeconomic researchers advocating sustainable agricultural development.

\section{Declarations}

\section{Ethics approval and consent to participate}

\section{Not applicable}

\section{Consent for publication}

Not applicable

\section{Availability of data and materials}

The datasets used and/or analyzed during the current study are available from the corresponding author on reasonable request.

\section{Competing interests}

The authors declare that they have no competing interests.

\section{Funding}

This study was supported by the National Natural Science Foundation of China (41822701 and 41773068), National Key Research and Development Project of China (2018YFC0213300), Major Science and Technology Program for Water Pollution Control and Treatment (2017ZX07401002), the Fundamental Research Funds for the Central Universities (2019XZZX004-11) and Discovery Early Career Researcher Award of the Australian Research Council (DE170100423).

\section{Authors' contributions}

Conceptualization: [Baojing Gu];

Methodology: [Yingliang Yu];

Formal analysis and investigation: [Yingliang $\mathrm{Yu}, \mathrm{Yu} \mathrm{Hu}$ ];

Writing - original draft preparation: [Baojing Gu];

Writing - review and editing: [Stefan Reis];

Funding and resource acquisition: [Linzhang Yang, Baojing Gu].

\section{Acknowledgments}

We thank Shenghan Gao from The Hong Kong University of Science and Technology for the help on preliminary data analysis. The contributions of SR were supported by the UK Natural Environment Research Council (NERC) National Capability award Sustainable Use of Natural Resources to Improve Human Health and Support Economic Development (SUNRISE) (NE/R000131/1)/

\section{References:}

Adamopoulos T, Restuccia D (2014) The Size Distribution of Farms and International Productivity Differences Am Econ Rev 104:1667-1697 doi:10.1257/aer.104.6.1667 Chen X et al. (2014) Producing more grain with lower environmental costs Nature 514:486-489 doi:10.1038/nature13609 
Du Z, Liu W (2017) Dual subjective status of family farm on its management and service Theoretical Investigation:80-85

Ebenstein A (2012) The Consequences of Industrialization: Evidence from Water Pollution and Digestive Cancers in China Review of Economics \& Statistics 94:186201

Fan L et al. (2019) Decreasing farm number benefits the mitigation of agricultural nonpoint source pollution in China Environ Sci Pollut R 26:464-472 doi:10.1007/s11356-018-3622-6

FAO (2020) FAOSTAT: FAO Statistical Databases., Rome, Italy

Gu B et al. (2012) Atmospheric Reactive Nitrogen in China: Sources, Recent Trends, and Damage Costs Environ Sci Technol 46:9420-9427 doi:10.1021/es301446g

Gu B, Ge Y, Chang SX, Luo W, Chang J (2013) Nitrate in groundwater of China: Sources and driving forces Glob Environ Chang 23:1112-1121 doi:10.1016/j.gloenvcha.2013.05.004

Gu B, Ju X, Chang J, Ge Y, Vitousek PM (2015) Integrated reactive nitrogen budgets and future trends in China Proc Natl Acad Sci USA 112:8792-8797 doi:10.1073/pnas.1510211112

Guo JH et al. (2010) Significant Acidification in Major Chinese Croplands Science 327:1008-1010 doi:10.1126/science. 1182570

Hu Y, Li B, Zhang Z, Wang J (2019) Farm size and agricultural technology progress: Evidence from China J Rural Stud

Jing L, Rodriguez D, Tang X (2017) Effects of land lease policy on changes in land use, mechanization and agricultural pollution Land Use Policy 64:405-413

Ju X et al. (2009) Reducing environmental risk by improving $N$ management in intensive Chinese agricultural systems Proc Natl Acad Sci USA 106:3041-3046

Ju X, Gu B (2014) Status-quo, problem and trend of nitrogen fertilization in China Journal of Plant Nutrition \& Fertilizer 4:783-795

Ju X, Gu B, Wu Y, Galloway JN (2016) Reducing China's fertilizer use by increasing farm size Glob Environ Chang 41:26-32 doi:10.1016/j.gloenvcha.2016.08.005

Ke J et al. (2018) Combined controlled-released nitrogen fertilizers and deep placement effects of $\mathrm{N}$ leaching, rice yield and $\mathrm{N}$ recovery in machine-transplanted rice Agri Eco Environ 265:402-412

Lassaletta L, Billen G, Grizzetti B, Anglade J, Garnier J (2014) 50 year trends in nitrogen use efficiency of world cropping systems: the relationship between yield and nitrogen input to cropland Environ Res Lett 105011:105011

Liu X, Sheng H, Jiang S, Yuan Z, Zhang C, Elser JJ (2016) Intensification of phosphorus cycling in China since the 1600s Proc Natl Acad Sci USA 113:2609-2614 doi:10.1073/pnas.1519554113

Norse D, Ju X (2015) Environmental costs of China's food security Agri Eco Environ 209:5-14 doi:10.1016/j.agee.2015.02.014

Reardon T, Timmer CP (2014) Five inter-linked transformations in the Asian agrifood economy: Food security implications. Global Food Security 3:108-117

Ren C, Liu S, van Grinsven H, Reis S, Jin S, Liu H, Gu B (2019) The impact of farm size on agricultural sustainability J Clean Prod 220:357-367 
doi:10.1016/j.jclepro.2019.02.151

Waller BE, Hoy CW, Henderson JL, Stinner B, Welty C (1998) Matching innovations with potential users, a case study of potato IPM practices Agr Ecosyst Environ 70:203-215

Wang G (2015) Problems and suggestions for developing family farms China State Finance:64-66

Wang X, Chen Y, Peng S, Peng Y, Yang X, Gao W (2017) Preliminary analysis on economic and environmental consequences of grain production on different farm sizes in North China Plain Agr Syst 153:181-189

$\mathrm{Wu}$ Y et al. (2018) Policy distortions, farm size, and the overuse of agricultural chemicals in China Proc Natl Acad Sci Usa 115:7010-7015 doi:10.1073/pnas.1806645115

Yan J, Chen C, Hu B (2019) Farm size and production efficiency in Chinese agriculture: output and profit China Agr Econ Rev 11:20-38

Ye J (2015) Land Transfer and the Pursuit of Agricultural Modernization in China J Agrar Change 15:314-337

Yu G et al. (2019) Stabilization of atmospheric nitrogen deposition in China over the past decade Nat Geosci 12:424-429 doi:10.1038/s41561-019-0352-4

Zhang C, Ju X, Powlson D, Oenema O, Smith P (2019) Nitrogen Surplus Benchmarks for Controlling N Pollution in the Main Cropping Systems of China Environ Sci Technol 53:6678-6687 doi:10.1021/acs.est.8b06383

Zhang W et al. (2016) Closing yield gaps in China by empowering smallholder farmers Nature 537:671-674

Zhang X, Davidson EA, Mauzerall DL, Searchinger TD, Dumas P, Shen Y (2015) Managing nitrogen for sustainable development Nature 528:51-59 doi:10.1038/nature15743

Zhong F (2016) Understanding issues regarding food security and rising labor costs Issues in Agricultural Economy 35:4-9 


\begin{tabular}{lcccc}
\hline & Smallholder & Family & Cooperation & Industrial \\
\hline $\begin{array}{l}\text { Attributes of farmers } \\
\text { Age }\end{array}$ & 63.3 & 41.8 & 43.1 & 44.3 \\
Education & & & & \\
$\quad$ Primary school (\%) & 45.5 & 13.2 & 0 & 0 \\
$\quad$ Middle school (\%) & 18.2 & 44.7 & 14.3 & 0 \\
$\quad$ High school (\%) & 31.8 & 42.1 & 35.7 & 11.1 \\
College/University & 4.5 & 0 & 50.0 & 66.7 \\
$\quad$ (\%) & 0 & 0 & 0 & 22.2 \\
$\quad$ Graduate (\%) & 86.4 & 96.2 & 100.0 & 89.9 \\
Male ratio (\%) & & & & \\
Attributes of croplands & $\mathrm{N}$ & $\mathrm{Y}$ & $\mathrm{Y}$ & $\mathrm{Y}$ \\
Transfer of land & 0.04 & 6.9 & 21.4 & 60.1 \\
Farm size (ha) & Neighborhood & Independent & Unified & Brand \\
Production objective & business & business & purchase & business \\
Inputs of machinery & & & & \\
Machinery purchase & Few & Few & Yes & Yes \\
Machinery use & Few & Yes & Yes & Yes \\
Number of households & 193 & 52 & 14 & 18 \\
Household share (\%) & 69.7 & 18.8 & 5.0 & 6.5 \\
Planting area (ha) & 7.7 & 357.1 & 298.7 & 1224.0 \\
Planting area share (\%) & $<1$ & 18.9 & 15.8 & 64.8 \\
\hline & & & & \\
\hline
\end{tabular}




\begin{tabular}{|c|c|c|c|c|c|}
\hline & \multicolumn{2}{|c|}{ Fertilizer input } & \multicolumn{2}{|c|}{ NUE } & \multirow{2}{*}{$\begin{array}{c}\text { Fertilizer } \\
\text { loss }\end{array}$} \\
\hline & OLS & 2 SLS & OLS & $2 \mathrm{SLS}$ & \\
\hline $\begin{array}{l}\text { Production } \\
\text { purposes }\end{array}$ & $\begin{array}{c}38.536 \\
(69.114)\end{array}$ & $\begin{array}{c}207.788 \\
(211.005)\end{array}$ & $\begin{array}{l}-0.070 \\
(.037)\end{array}$ & $\begin{array}{c}0.047 \\
(0.098)\end{array}$ & $\begin{array}{c}15.358 \\
(12.810)\end{array}$ \\
\hline Farm size & $\begin{array}{c}-.471 \\
(0.284)\end{array}$ & $\begin{array}{l}-0.449 \\
(0.303)\end{array}$ & $\begin{array}{l}4.235 \mathrm{e}-4^{* * *} \\
(1.406 \mathrm{e}-4)\end{array}$ & $\begin{array}{c}4.453 \mathrm{e}- \\
4 * * \\
(1.802 \mathrm{e}-4)\end{array}$ & $\begin{array}{l}-0.032 \\
(0.049)\end{array}$ \\
\hline $\mathrm{Age}^{2}$ & $\begin{array}{l}0.052 * * \\
(0.020)\end{array}$ & $\begin{array}{l}0.046^{* *} \\
(0.022)\end{array}$ & $\begin{array}{c}-2.96 \mathrm{e}- \\
5 * * * \\
(1.06 \mathrm{e}-5)\end{array}$ & $\begin{array}{c}-3.42 \mathrm{e}-5^{* *} \\
(1.40 \mathrm{e}-5)\end{array}$ & $\begin{array}{l}7.887 \mathrm{e}-3 * * \\
(3.674 \mathrm{e}-3)\end{array}$ \\
\hline Education & $\begin{array}{c}-25.492 * \\
(14.610)\end{array}$ & $\begin{array}{c}-8.948 \\
(24.806)\end{array}$ & $\begin{array}{c}9.422 \mathrm{e}-3 \\
(9.091 \mathrm{e}-3)\end{array}$ & $\begin{array}{c}0.033 \\
(0.021)\end{array}$ & $\begin{array}{c}2.160 \\
(3.146)\end{array}$ \\
\hline machinery use & $\begin{array}{c}-104.774 * \\
(56.907)\end{array}$ & $\begin{array}{c}-320.111 \\
(258.8108)\end{array}$ & $\begin{array}{c}0.063 * * \\
(0.031)\end{array}$ & $\begin{array}{l}-0.113 \\
(0.136)\end{array}$ & $\begin{array}{c}-22.369 * * \\
(10.618)\end{array}$ \\
\hline Constant & $\begin{array}{c}505.898 * * * \\
(88.154)\end{array}$ & $\begin{array}{c}495.777 \\
* * * \\
\square 94.536)\end{array}$ & $\begin{array}{c}0.584 * * * \\
(.050)\end{array}$ & $\begin{array}{c}0.552 * * * \\
(0.068)\end{array}$ & $\begin{array}{l}33.793 * \\
(17.426)\end{array}$ \\
\hline$N$ & 63 & 63 & 43 & 43 & 43 \\
\hline Wald chi2 & & 58.51 & & 31.68 & \\
\hline $\mathrm{F}$ & 13.58 & & 10.96 & & 4.40 \\
\hline R-squared & 0.544 & 0.4289 & 0.597 & 0.236 & 0.373 \\
\hline
\end{tabular}

637 Standard errors in parentheses. $* * * \mathrm{p}<0.01, * * \mathrm{p}<0.05, * \mathrm{p}<0.1$. Labor productivity is 638 used as the IV for the 2SLS-IV analysis to test the robustness of the models. OLS, 639 ordinary least squares; 2SLS, two-stage least squares.

640 
643 Fig. 1. Changes of paddy yield, fertilizer use, loss and use efficiency of different 644 farming models. (a) paddy yield; (b) fertilizer use; (c) fertilizer loss; (d) N fertilizer use 645 efficiency. Different letters above the bars represent significant difference at $p<0.05$ level, 646 with the same letter representing no significant difference.

Fig. 2. Cost and benefit of agricultural practices of different farming models. (a) total cost for production; (b) net profit of production; (c) cost profit ratio (profit/cost); (d) labor productivity per year per capita. In (a), filled bars represent fixed input and dashed bars represent non-fixed input. Different letters above the bars represent significant difference at $p<0.05$ level, with the same letter representing no significant difference.

Fig. 3. Changes of planting area under different farming models and total fertilizer loss for the whole study region from 2013 to 2018. (a) Share of planting area; (b) fertilizer loss of the study region.

Fig. 4. Response of labor productivity, fertilizer use efficiency and loss to fixed input ratio, farmers' age and educational level. (a)-(c) labor productivity; (d)-(f) fertilizer use efficiency; (g)-(i) fertilizer loss with fixed input ratio, farmers' age and educational level, respectively. The educational levels from 1 to 5 refer to primary school, middle school, high school, college/university, and graduate, respectively.

Fig. 5. Response of fixed input ratio, farmers' age and educational level to farm size. (a) fixed input ratio; (b) age; (c) educational level with Ln farm size, respectively. The educational levels from 1 to 5 refer to primary school, middle school, high school, college/university, and graduate, respectively. 
Figure 1
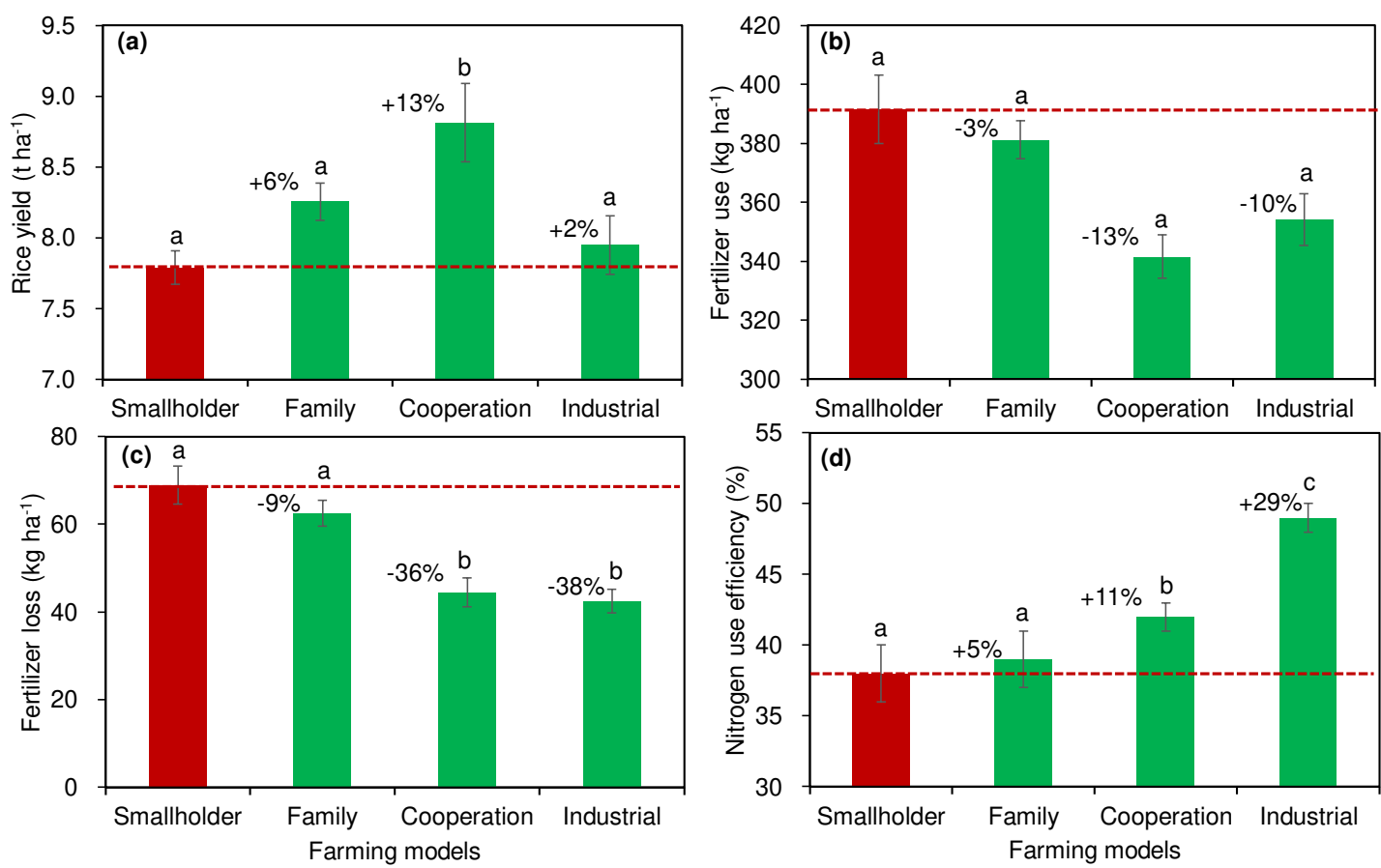

670

671 
673
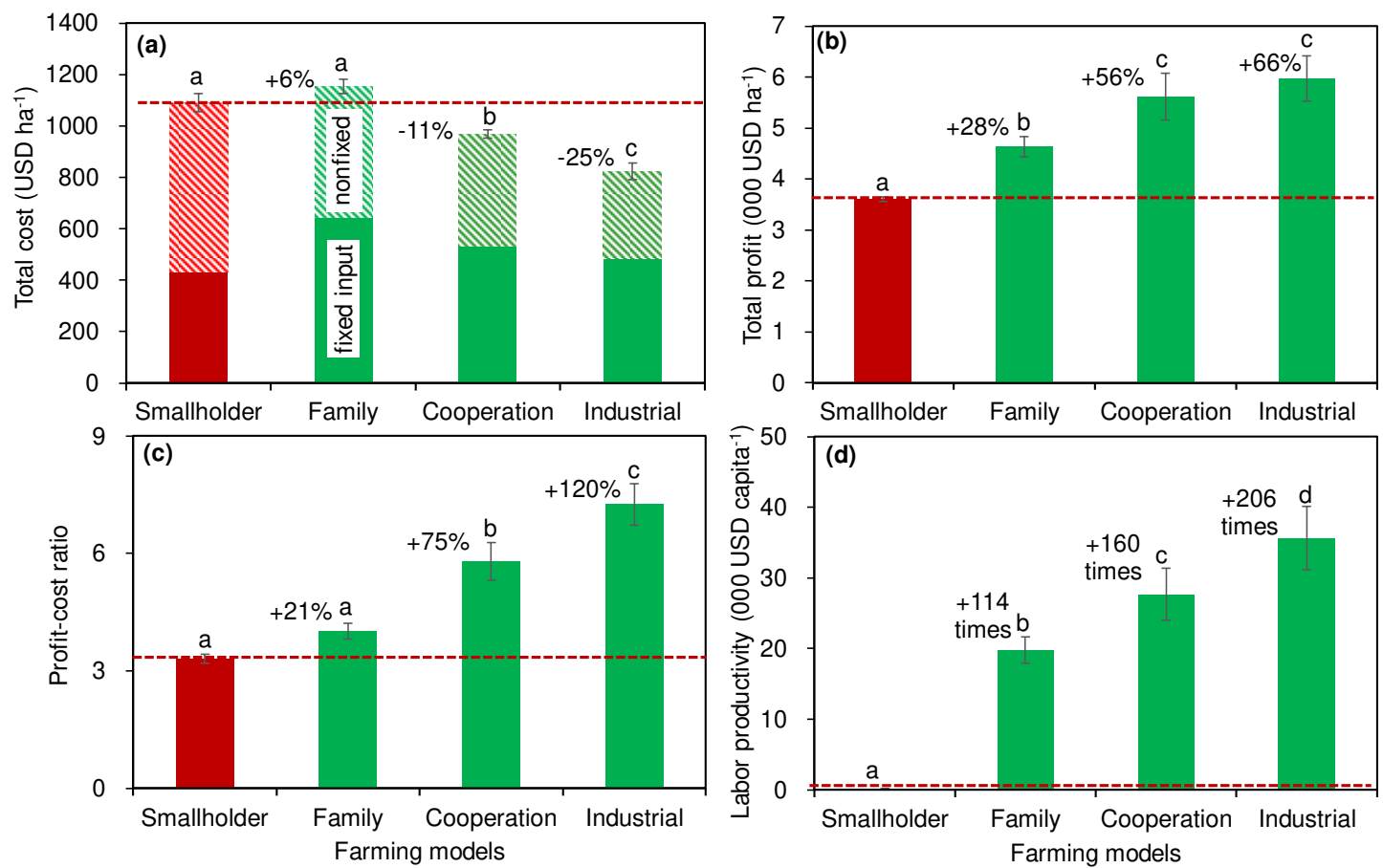


\section{$676 \quad$ Figure 3}

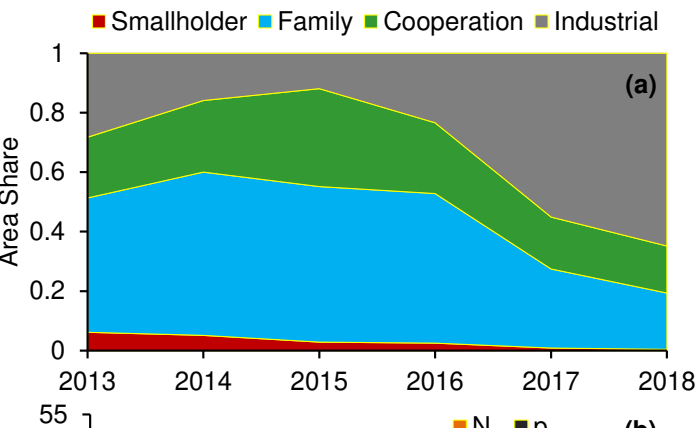

677

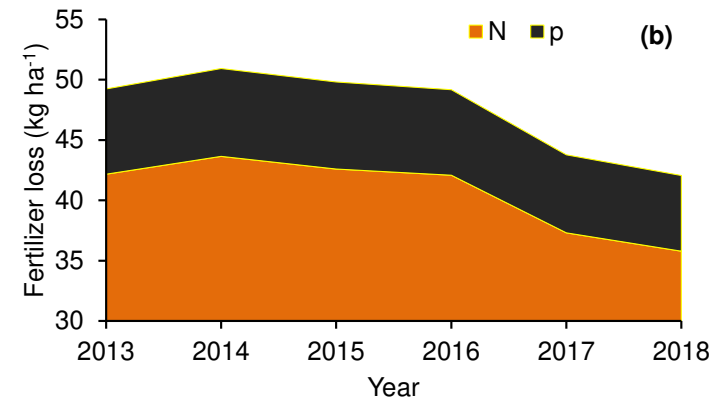


679
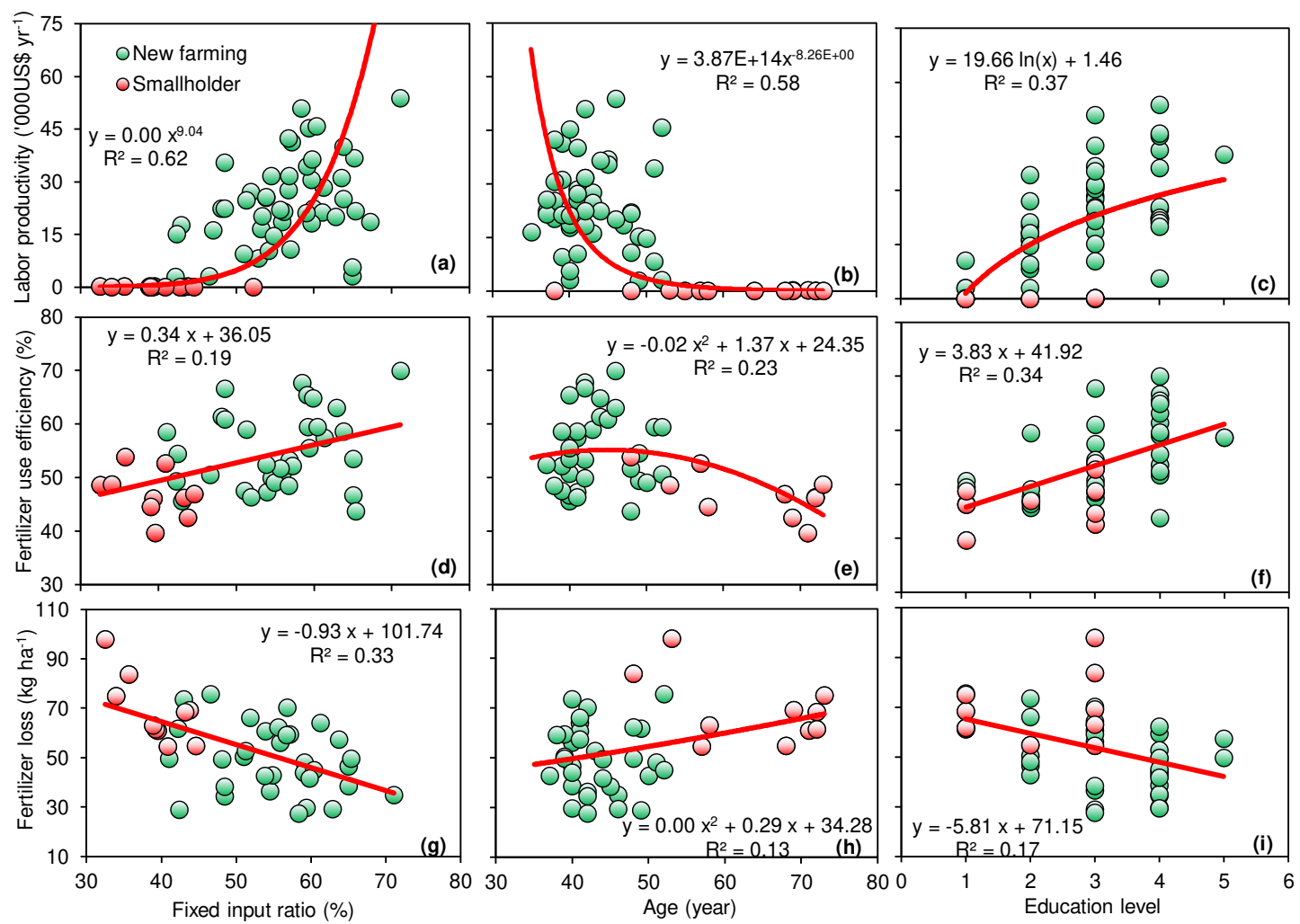

680

681 
Figure 5
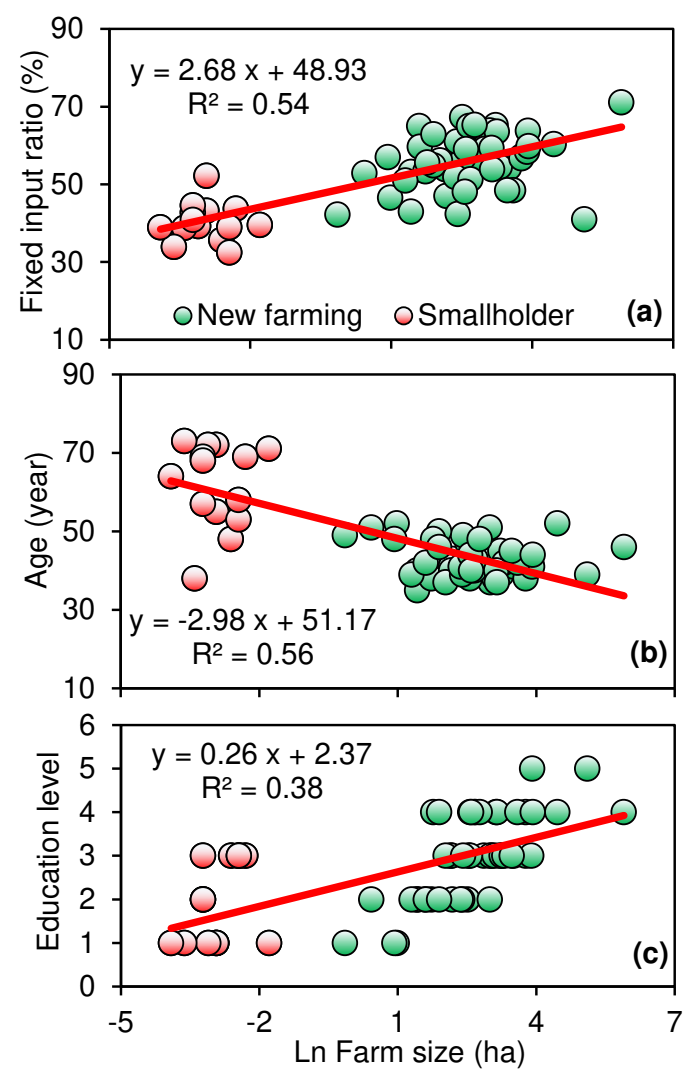

683

684 
685

686

687

688

\section{TOC Graphic}

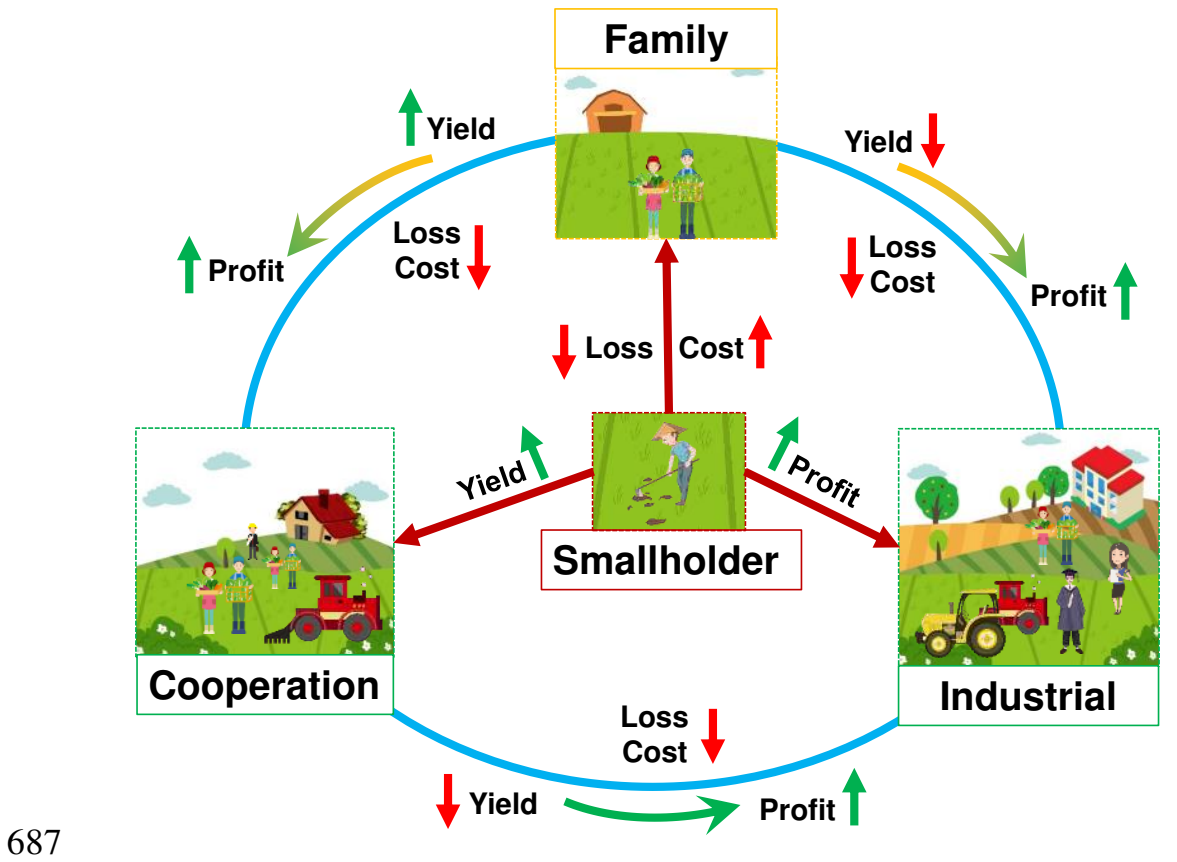


Figures
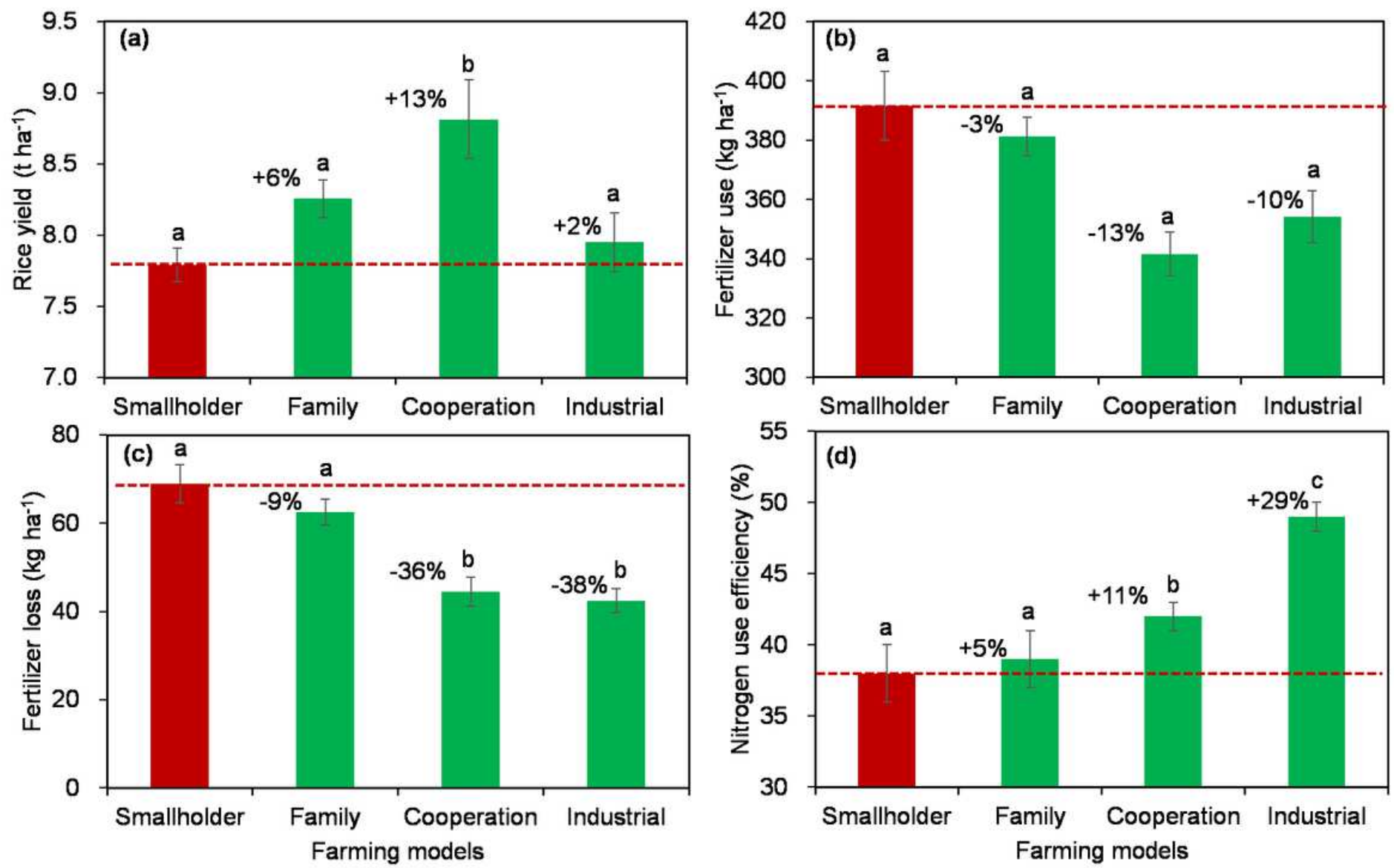

Figure 1

Changes of paddy yield, fertilizer use, loss and use efficiency of different farming models. (a) paddy yield; (b) fertilizer use; (c) fertilizer loss; (d) $\mathrm{N}$ fertilizer use efficiency. Different letters above the bars represent significant difference at $p<0.05$ level, with the same letter representing no significant difference. 

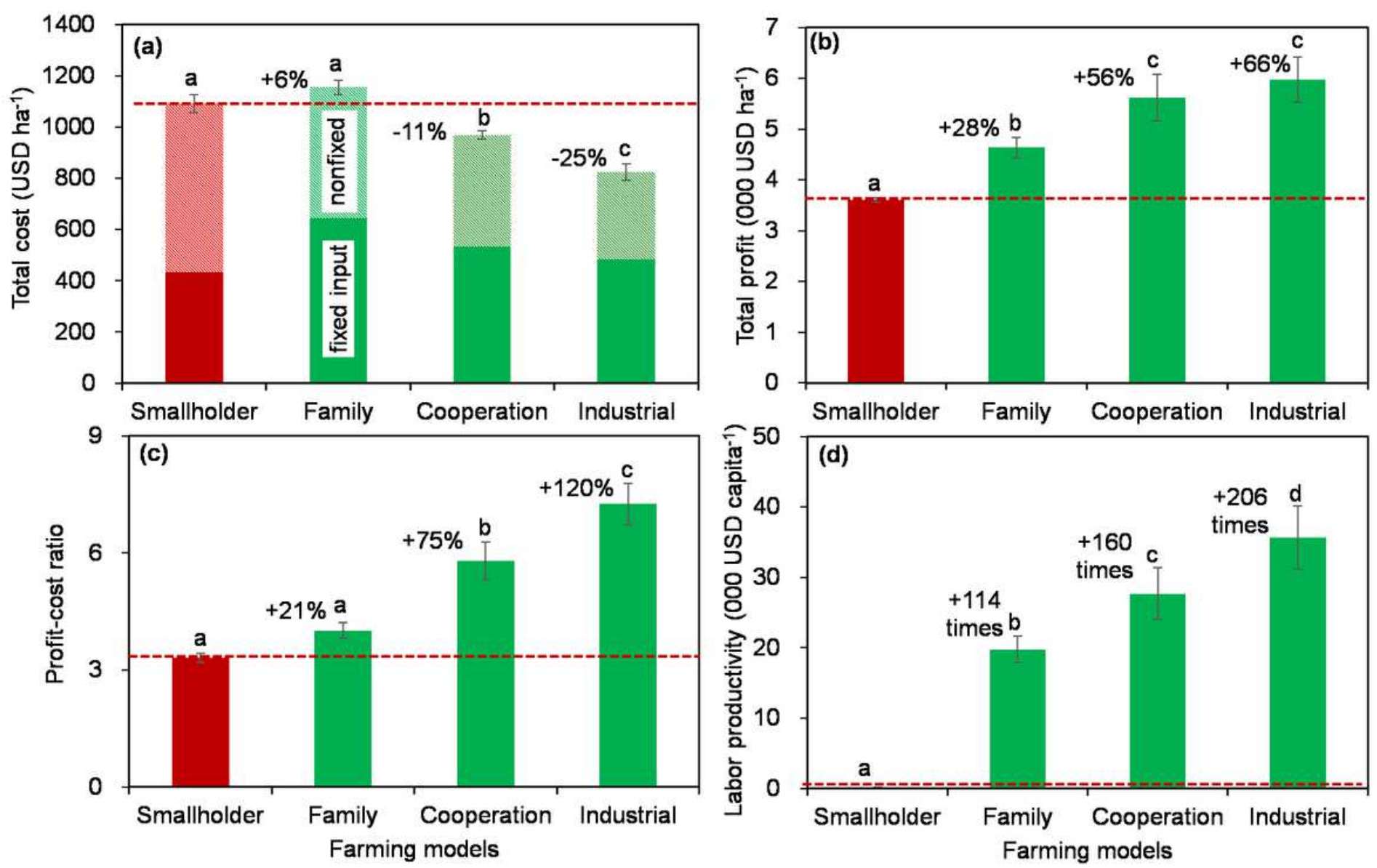

Figure 2

Cost and benefit of agricultural practices of different farming models. (a) total cost for production; (b) net profit of production; (c) cost profit ratio (profit/cost); (d) labor productivity per year per capita. In (a), filled bars represent fixed input and dashed bars represent non-fixed input. Different letters above the bars represent significant difference at $p<0.05$ level, with the same letter representing no significant difference. 


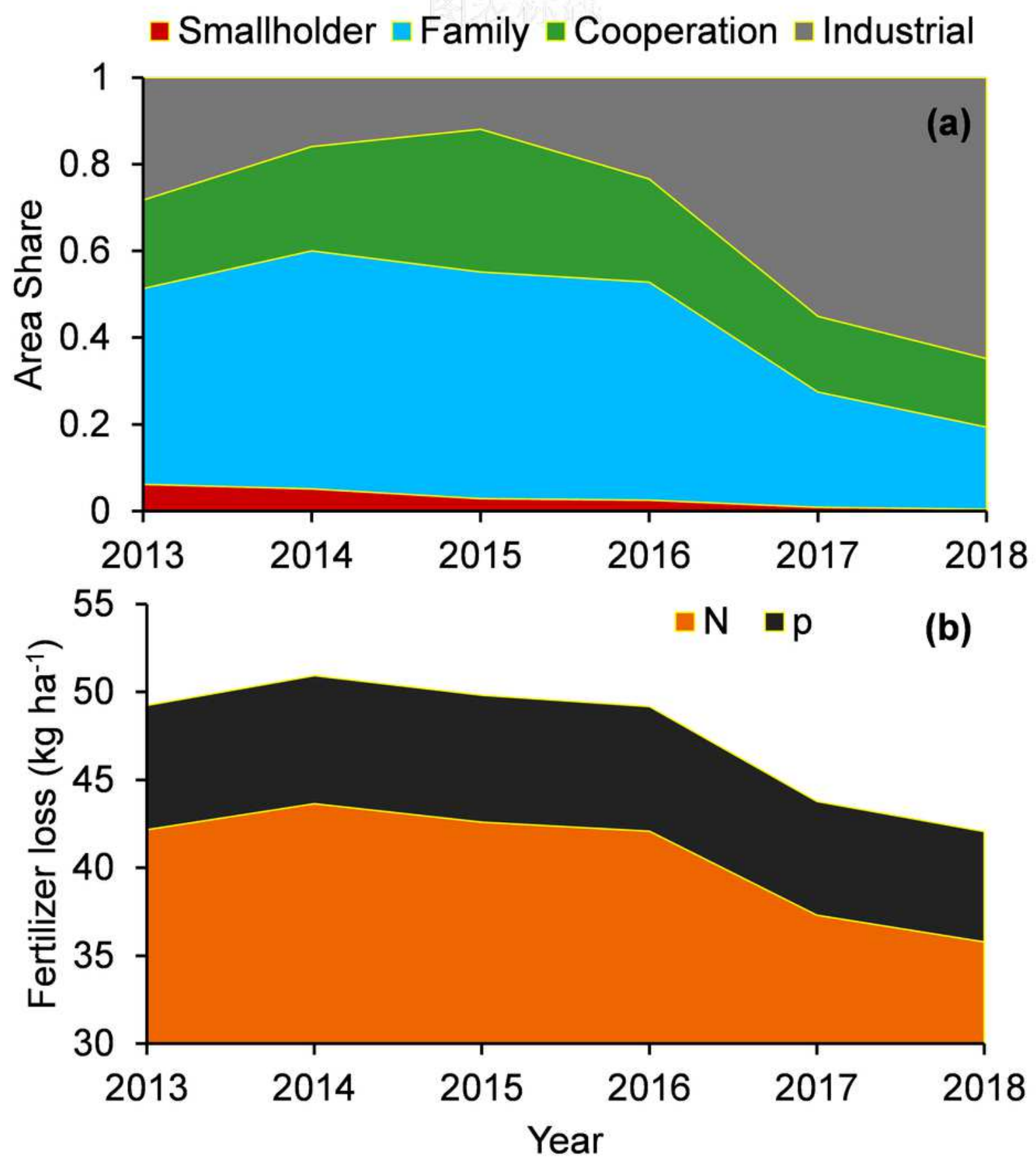

Figure 3

Changes of planting area under different farming models and total fertilizer loss for the whole study region from 2013 to 2018. (a) Share of planting area; (b) fertilizer loss of the study region. 

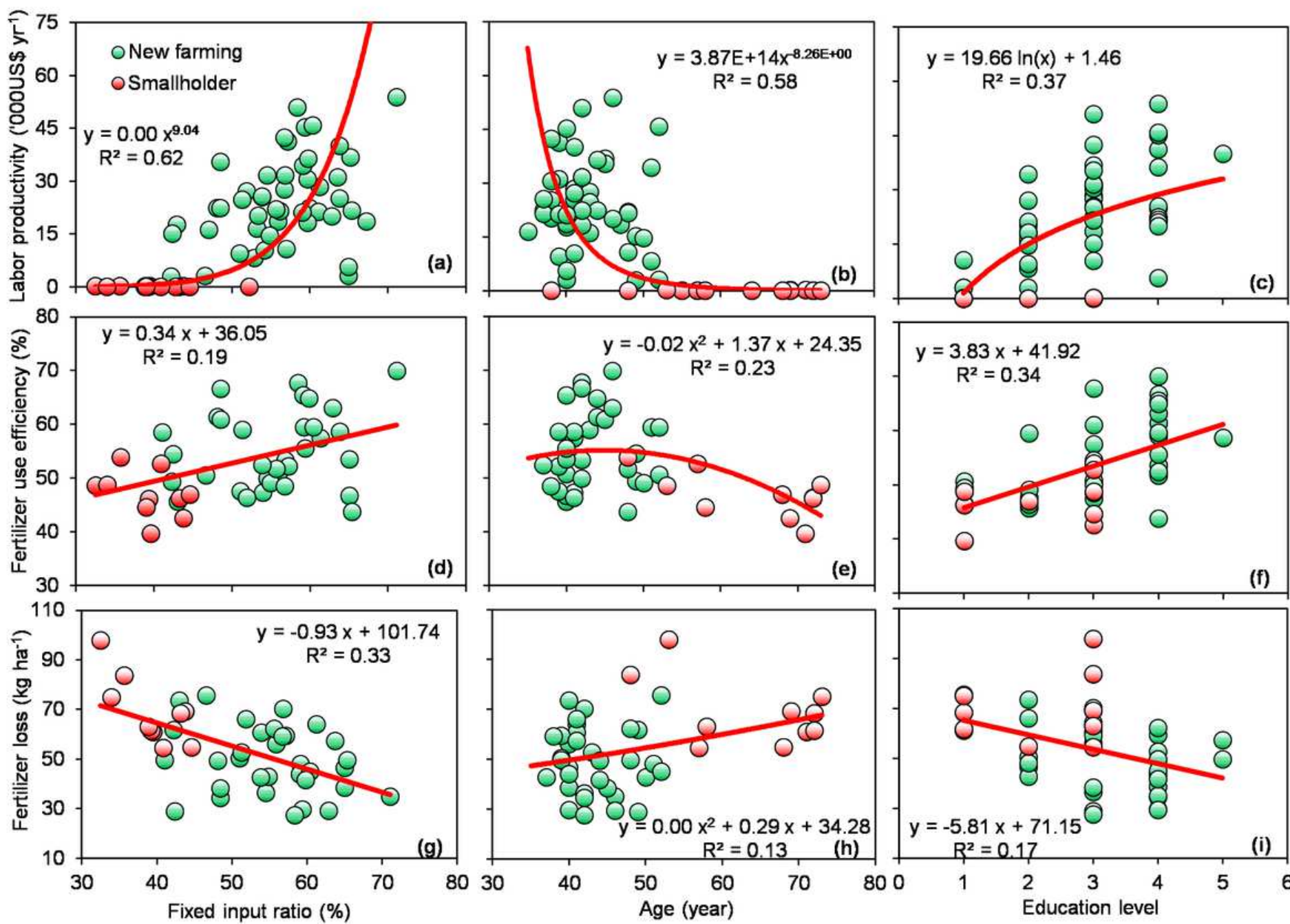

\section{Figure 4}

Response of labor productivity, fertilizer use efficiency and loss to fixed input ratio, farmers' age and educational level. (a)-(c) labor productivity; (d)-(f) fertilizer use efficiency; (g)-(i) fertilizer loss with fixed input ratio, farmers' age and educational level, respectively. The educational levels from 1 to 5 refer to primary school, middle school, high school, college/university, and graduate, respectively. 

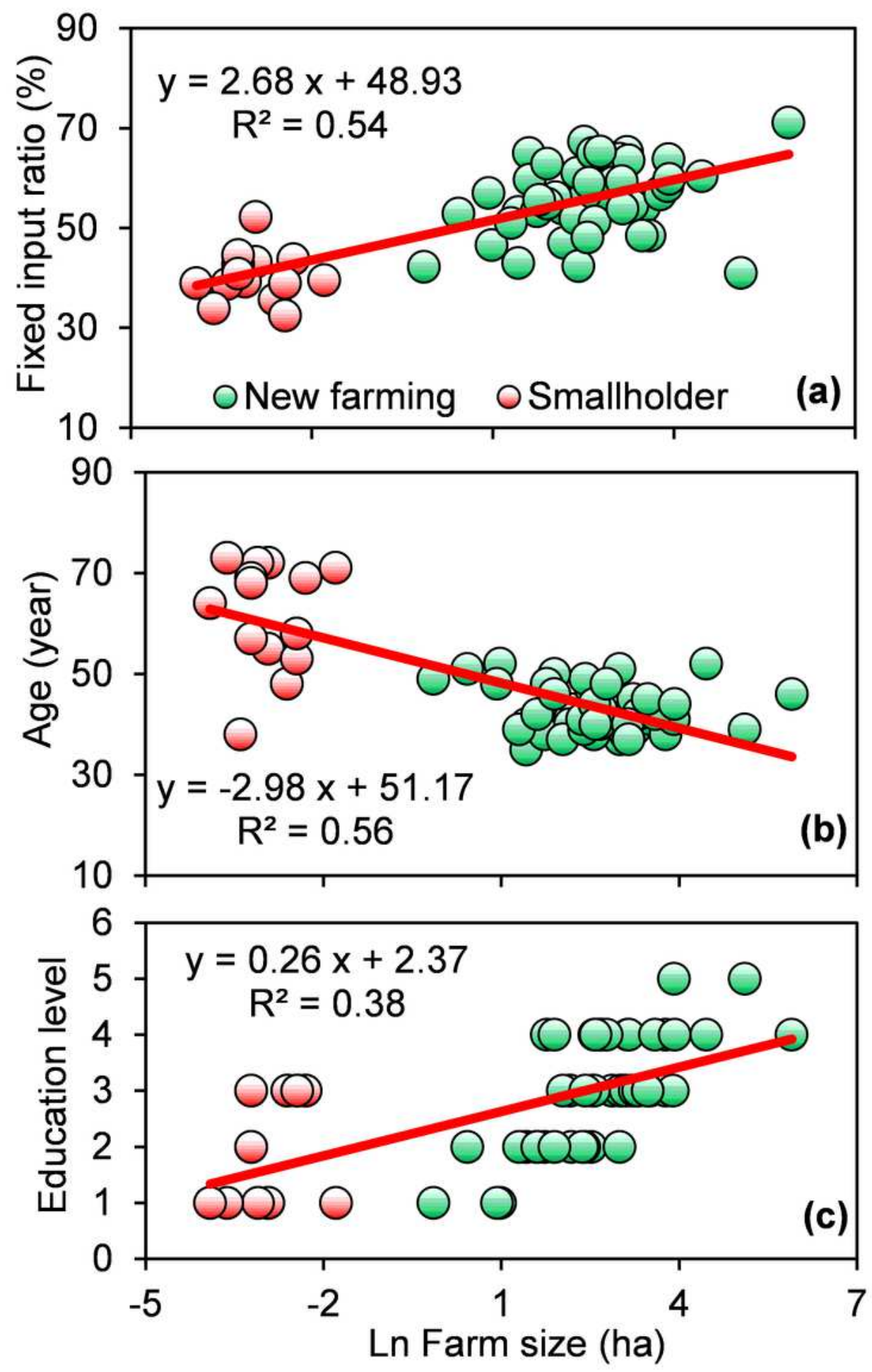

Figure 5

Response of fixed input ratio, farmers' age and educational level to farm size. (a) fixed input ratio; (b) age; (c) educational level with Ln farm size, respectively. The educational levels from 1 to 5 refer to primary school, middle school, high school, college/university, and graduate, respectively. 
This is a list of supplementary files associated with this preprint. Click to download.

- TOCGraphic.png 